\title{
An Assessment of Outsourcing of Offshore Call Centres on Customer Service in Commercial Banks: A Case of Zambia
}

\author{
Zillah Nkonde1, Jackson Phiri² \\ ${ }^{1}$ Graduate School of Business, University of Zambia, Lusaka, Zambia \\ ${ }^{2}$ Department of Computer Science, School of Natural Sciences, University of Zambia, Lusaka, Zambia \\ Email:nkondezillah@gmail.com, jackson.phiri@cs.unza.zm
}

How to cite this paper: Nkonde, Z., \& Phiri, J. (2020). An Assessment of Outsourcing of Offshore Call Centres on Customer Service in Commercial Banks: A Case of Zambia. Open Journal of Social Sciences, 8, 296-310.

https://doi.org/10.4236/jss.2020.82023

Received: December 2, 2019

Accepted: February 25, 2020

Published: February 28, 2020

Copyright $\odot 2020$ by author(s) and Scientific Research Publishing Inc. This work is licensed under the Creative Commons Attribution International License (CC BY 4.0).

http://creativecommons.org/licenses/by/4.0/

\begin{abstract}
Call Centres can be considered as important channels of communication in an organisation as they are the first point of integration between call centre agents that represent the business and customers. Therefore, it is key that agents should be correctly sizing the opportunity of any given call, because a Call Centre can bring benefits not only in terms of improved customer service through efficiency, but also in terms of increasing market share through effectiveness. This paper sorts to assess outsourcing of offshore call centres on customer service as most studies have not yet examined impact of offshore call centres on customer service in Zambian commercial banks. In order to address this gap, this study explores the different types of call centres, challenges faced and discuss what would help the organisations grow in market share and at the same time deliver excellent customer service. The study was based on 125 commercial bank customers. Purposive sampling was used in the study. Descriptive statistics and correlation were used to analyse the data. The results show that the call centre is a very important aspect of customer relations as all the customers sampled indicated that they utilise the call centre line for various services ranging from balance inquiries, account transactions, internet banking services, mobile banking services as well as other inquiries. Following the various challenges experienced by customers as shown in the results, it is therefore concluded and recommended that creating local call centres in Zambia would help so much in alleviating these challenges and improve customer experience.
\end{abstract}

\section{Keywords}

Call Centre, In House, Offshore, Outsource, Service, Customer Service, Customer Satisfaction 


\section{Introduction}

In recent years, the importance of Call Centres has increased tremendously in the customer care industry. Afrika (2012) states that managing the customer experience resulting from Call Centre encounters is likely to have major impact on an organization's success. Miciak as sited by Kim and Ha (2010) states that Call centers play a critical role in today's business world, and for many organizations they are the primary source of contact for customers. Call centres are important constituents of services that organizations offer customers by means of solving problems, resolving complaints and providing information (Lywood et al., 2009). Therefore, managing very well customer interactions or experiences with the call centre would help businesses to improve customer service delivered that eventually trickles down to improved customer satisfaction.

\subsection{Background}

There has been an increase in the number of complaints after call centres were outsourced internationally compared to when they were in house or local. Govender (2016) states that Call Centres have been regarded as an enabling resource for enhanced customer service and experience and this is even more so in the dynamic mobile telecommunications industry where technology evolution is rapid and customer loyalty extends only as far as their last "bad" experience. This study endeavoured to assess the outsourcing of offshore call centres on customer service. The study further explores the impact of outsourcing of offshore Call Centres on customer service are based on the customers' experience. Since Call Centres are one of customer's points of contact with an organization, their experience with the Call Centre staff contributes to their perception of the quality of service provided and the degree of satisfaction.

\subsection{Significance of the Study}

The significance of this research is the value it is expected to add to the banking industry in Zambia. As acquiring new customers can cost five times more than satisfying and retaining current customers (Webber \& Brown, 2008). Therefore, from the challenges experienced by both customers and Call centre agents a solution model has been developed that will lead to increased customer satisfaction which is having a local call centre.

\section{Literature Review}

\subsection{Call Centre}

Kurniali and Titan (2015) define a call center as a centralized office meant for the purpose of receiving and transmitting a large volume of information by telephone. They further stated that call centers are required for large companies to sell or promote their goods and services as well as for the after sales services and customer queries and complaints management. In simpler terms a Call center acts as an interface between the customer and a company where they can call 
and report problems or ask for information regarding products or services offered by an organization.

\subsection{Types of Call Centres}

There are several types of call centres but the researcher will only list four. Whether it is a service-oriented company or a product-based organisation, excellent customer service delivery should be a top priority for all those who want to make a mark and increase market share. Therefore, a swift, accurate and professional response to customer requests, queries and complaints not only helps to retain and return a happy customer but also imparts assurance in the brand. According to the 2013 survey by Deloitte titled "2013 Global Contact centre Survey Results" (Global Contact Center Survey, 2013), it shows that around 77\% of contact centres were planning to grow in size by 2014-15, driven by the need to improve customer interaction/service and improve business growth

\subsection{Outbound Call Centre}

According to Rouse (2017) in an out bound call centre, an agent makes calls on behalf of the company or client for tasks, including lead generation, telemarketing, customer retention, fundraising, surveying, collecting debts or scheduling appointments.

\subsection{Inbound Call Centres}

An inbound call centre works slightly like an outbound call centre in reverse, although there are a few key distinctions. Rouse (2017), elaborates that typically, an inbound call centre handles a considerable volume of calls at the same time, screens and forwards calls to someone qualified to handle them and logs.

\subsection{In-House Call Centre}

In this business model, the call center is within the organization. Many businesses decide to set up their own call centres, within their business premises, and staffed with their own people (Belyh, 2016).

\subsection{Outsourced Call Centres}

Call centre outsourcing is the business practice of contracting out call centre services (Amadeo, 2019). As stated above call centres cover a wide area that includes marketing, sales, customer service, technical support, telemarketing and financial management.

\subsection{Banking Industry and Different Services}

The banking system plays a very important role in the economy. According to a survey report by the Price Waterhouse and Coopers (PWC) (2017) they stated that the banking industry has opportunities to grow through:

1) Technology enabled products and services which are now firmly at the 
frontier of product and service development and enhancing the customer experience.

2) Financial inclusion: in order for the banks to be able to reach the unbanked and tap into the potential they should make it a priority.

\subsection{Customer Service}

For an organization that truly puts the customer at the centre of business (customer centric), quality of service excellence means to do the job the right way (Kurtovic \& Hasimbegovic, 2015). In the past few years, the financial sector in Zambia has undergone major changes. Additionally, Amoako (2012) states that globalisation, mergers and acquisitions, and the emergence of new technologies have contributed dramatically to stiffer competition and pressures on profitability. Therefore, in such a competitive market, attracting profitable customers should be a priority of all the financial institutions especially in banks. Therefore, the question is what is required to attract, maintain and excite customers in the banking sector in Zambia?

\subsection{Theoretical Review}

Reynolds in Govender (2016) defines a Call Centre as "a place where contact is made and received" and a single point of contact for customers to get help and solve queries, complaints and concerns. Furthermore, Call Centres do not only deal with customers' complaints, but with the sales aspects of the organization as well.

\subsection{Customer Satisfaction Theory}

Customer satisfaction should be high on the list of priorities for organisations such as banks, as this will result in customer loyalty, certainly retention and would also attract potential customers. Kotler as cited in Clinton and Wellington (2013) defined satisfaction as "a person's feeling of pleasure or disappointment resulting from comparing a product's perceived performance (or outcome) in relation to his or her expectations. Customer satisfaction is therefore, very important in that it helps the business know how they are performing which would further help them take the right direction to either continue what they are doing or find other ways to improve service delivery. This clearly shows that Customer satisfaction does have a positive effect on an organization's profitability. Khadka \& Maharjan (2017) shared that when the customer is satisfied with the product or service of the company, it can make the customer to purchase frequently and to recommend products or services to potential customers. It is impossible for a business organization to grow up in case the company ignores or disregards the needs of customers (Tao, 2014).

\subsection{Service Quality Theory}

Service quality (ServQual) is a comparison of expectations (E) about a service 
with performance (P) SQ = P-E (Kalaiselvi, 2016). Kalaiselvi further states that a business with high service quality will meet customer needs whilst remaining economically competitive. Angelova and Zeqiri (2011) stipulate that service quality and customer satisfaction are very important concepts that companies must understand if they want to remain competitive and grow.

Therefore, communication is one of the factors in the SERVQUAL framework. A customer with a service issue may find their frustration intensified by difficulties in being understood by the customer service agent.

\subsection{Word of Mouth Theory}

The development in online platforms such as blogs and social networking sites (SNS) has resulted in significant changes to information distribution and marketing communications. Koeck \& Marshall (2015) revisited the "two-step flow of communication", that includes "opinion leaders" as information conduits who filter information and pass it to their peers via word of mouth (WOM) with their own interpretations. The information shared could either be encouraging (positive) or discouraging (negative) other customers from using a service or product of the firm that is being talked about.

This shows that it is key to have excellent service quality in a call centre as it can help with positive word of mouth that would further help with increasing market share of the organisation.

\subsection{Loyalty and Relationship Theory}

Relationship theories indicate the benefits of creating relationships with customers which leads to building of customer loyalty. The purpose of building relationships with customers is to retain customers in the existing company. Therefore, by retaining them the loyalty is created and loyalty in turn, results in superior long-term financial performance. Researchers such as Kranias \& Bourlessa (2010) define loyalty as the biased behavioral response expressed over time by customers with respect to one provider out of many providers accompanied by a favorable attitude. Therefore, loyalty building requires the company or an organization to emphasize on the value of its products and services and to show that it is interested in fulfilling the desire of building the relationship with customers.

This can come from good customer service that customers receive from call centres that can determine customer loyalty and good relationships.

\subsection{Empirical Review}

This study closely refers to a simple model developed by the Delphi Research Team. This model predicts that a $1 \%$ decrease in customer satisfaction can cause a $0.6 \%$ decrease in customer loyalty. When this statement is further simplified it means, a $10 \%$ drop in customer satisfaction can lead to a $6 \%$ drop in customer loyalty. This shows that customer satisfaction is always fundamental as agents 
often communicate with customers.

The study also reviewed estimates from the Call Centre Satisfaction Index2 (CCSI 2019) and other industry sources which indicate that when a U.S. caller has reached a contact centre, between $15 \%$ and $20 \%$ of those think they have contacted an offshore contact centre. The study shows that a call centre location impacts about one in two callers relative to the decision with whom they want to do business. Some customers would rather go the branch in person as opposed to them just calling the call centre with reason being not local employees will answer the call.

Customers who believe they are dealing with an offshore contact centre are more than twice as likely to sever relations with the company.

\subsection{Related Works}

A study by Abdullateef, Muktar, Yusoff and Ahmad (2014) titled Effects of Customer Management Strategy on Call Centre’s Employee Intention to Quit: Evidence from Malaysia Call Centres Relationship discusses about call centres in Malasia, some common problems and various dimensions management must properly utilise to in order to get the desired results in line with customer relationship management. However, the study only looks at customer relationship management in line with employee retention. Another study by Xia et al. (2015) titled Competition and market segmentation of the call centre service supply chain, it looks at coexistence conditions for multiple call centres. It further makes cost analysis for multiple call centres. This study fell short in that it did not look how a single call centre can be structured and operated in order to improve service delivery.

A study by Zhu (2016) entitled managing the risks or outsourcing: Time, quality and correlated costs, the author states that these three factors are the main factors for outsourcing management. In this paper they considered outsourcing scenario where a buyer outsources products or services to a supplier. In another study done by Kim, Park, Jung and Park (2017) titled: Offshoring and outsourcing in a global supply chain: Impact of the arm's length reg-ulation on transfer pricing. The literature gathered analytically shows the trade-off in the Multinational firm choice of the organisational structure considering production cost and tax rate differential. However, several directions remain worthy of investigation. This study assumes simple uniform distribution for outsourcing and does not include logistic costs of facility setup costs in offshoring or the impact outsourcing has on customers. A study by Jouini et al. (2010) entitled Online scheduling policies for multiclass call centres with impatient customers. This study has given some structural results that will help to better understand the impact of different scheduling policies on the performance measures of interest. However, the study only focused their analysis on a given period of day and on two classes of customers.

All the above studies were of great significance in that they outlined various 
aspects that can lead to successful operations of offshore outsourced call centres. However, none of them had a holistic approach that would cover meeting both the customer needs and the business objectives, hence making this study relevant.

\section{Conceptual Framework}

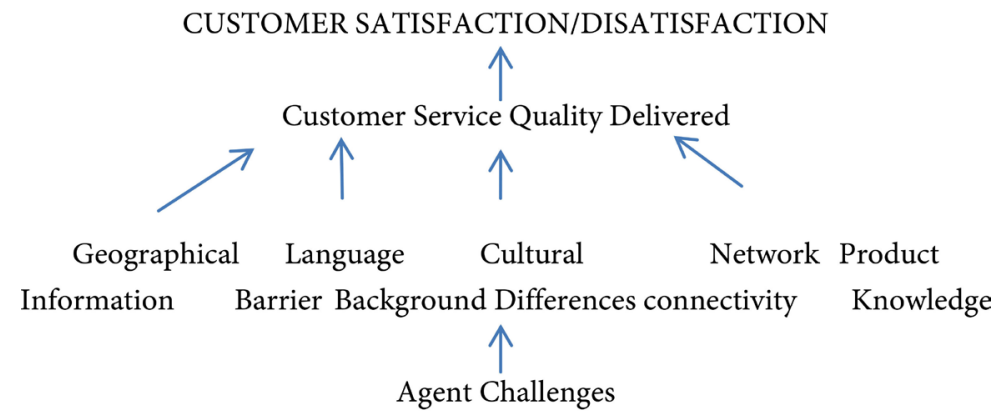

Above is a conceptual framework leading to customer satisfaction/dissatisfaction derived from call centre services. Geographical information awareness of a country by agents would enable quality customer service delivery as agents are able to effectively advise customers alternative locations, they can access service from. Similarly, language barrier and cultural background differences would affect the quality of service delivery as it would impede effective communication between customer and call centre agent. On the other hand, while network connectivity is not directly linked to call centre agents, network connectivity of mobile service providers used by customers can affect quality service perception. Finally, product knowledge by call centre agents directly affects their ability to provide comprehensive information on various products and services available to the customer.

The current model of the call centre is offshore and outsourced, from the research results, the challenges customers shared clearly show that a local call centre will greatly improve service delivery in that the challenges that the agents are currently facing can easily be managed by local call centre agents. Therefore, in line with the customer satisfaction theory, this study has settled for the local call centre as will be shown in the coming chapters below.

\subsection{Data Collection Methods}

The study used primary data as opposed to secondary data because of the inherent advantages of primary data. The advantages are that the data is original and relevant to the topic of the research study so the degree of accuracy is very high because these are collected by the concerned and reliable party.

The researcher used a comprehensive semi-structured questionnaire to collected data that was designed to cover major aspects of outsourcing offshore call centre services. The questionnaire included both open and closed ended questions. 


\subsection{Data Analysis Methods}

After coding the responses from each questionnaire, the researcher used Statistical Package for Social Sciences version 20 (0028SPSS V20) for data entry.

Qualitative responses were tallied and themes created which helped group the responses and made the analysis easier. Additionally, qualitative research believes in words, expression and content analysis while it comes in the phase of analysis. Thus, qualitative data analysis provided discerning, examining, comparing, contrasting and interpreting meaningful patterns. Hence, all questions were analysed with the development of themes or sub topics that helped in analysing the questionnaires in order to come up with in depth information.

\subsection{Target Population and Sampling Frame}

In this study our target population was all the customer populace of commercial Banks across Zambia that have outsourced call centres. Therefore, our sampling frame was a list of customers holding bank accounts with the banks. The study was based on a sample size of 125 customers. Purposive sampling, also known as criterion-based selection was used in this study. Purposive sampling (also known as judgment, selective or subjective sampling) is a sampling technique in which a researcher relies on his or her own judgment when choosing members of a population to participate in a study (Dudovskiy, 2016). Hence this study targeted customers of commercial Banks across Africa in various towns where there are banks with outsourced call centres in order to get an accurate picture of what is on the ground.

\subsection{Results from Analysis}

In this section the researcher presents the results from analysis of various relationships between challenges faced in using the outsourced offshore call centres and the variables under consideration. The gender distribution of the respondents. The majority of the respondents were females represented by $50.4 \%$ of the sampled respondents and males were represented by 49.6 .

\subsection{Utilisation of the Call Centre Number}

When the sampled respondents were asked if they used the call centre line, all the respondents indicated that they do. Therefore, it could be concluded that almost all the customers sampled have used the offshore call centre before.

In line with utilisation in Figure 1, the results show that the majority of the sampled respondents indicated that they did not often use the contact centre line, represented by $41.6 \%$ of the sampled respondents. $34.4 \%$ said that they moderately used the line while $13.6 \%$ indicated that they often used the line for their various bank services that they consume and $10.4 \%$ did not respond to the question. These results suggest that on average at least the respondents use the call centre line for various bank products and services that they consume. For those that do not often use the call centre line 5950 it could be attributed to the 
challenges outlined in the section below while others prefer going directly to their branches for their desired services and products.

Table 1 shows the results that were obtained on the services that the sampled respondents call for. According to the results in the table, the majority of about $68 \%$ indicated that they use the call centre line to call for account transactions, these were followed by those that said that they call for failed mobile banking services who were $46.4 \%$. $28.8 \%$ of the sampled respondents indicated that they call line for purposes of failed internet banking services, $16 \%$ of the sampled respondents indicated that they use line for general inquiries while $13.6 \%$ of the respondents said that they call the line for internet banking related services and finally, $8 \%$ of the sampled respondents said that they call the line for balance inquiries. From these results, it shows that most of the respondents use the call centre line for purposes of account transactions services that they consume from the bank. These results also indicate that most of the customers make a lot of account transactions, mobile banking and internet banking services. These services among others are what prompts customers to call the offshore call centre line.

When asked if they were not satisfied with the service they received from the call centre agents, as shown in Table 2 the majority respondents of about

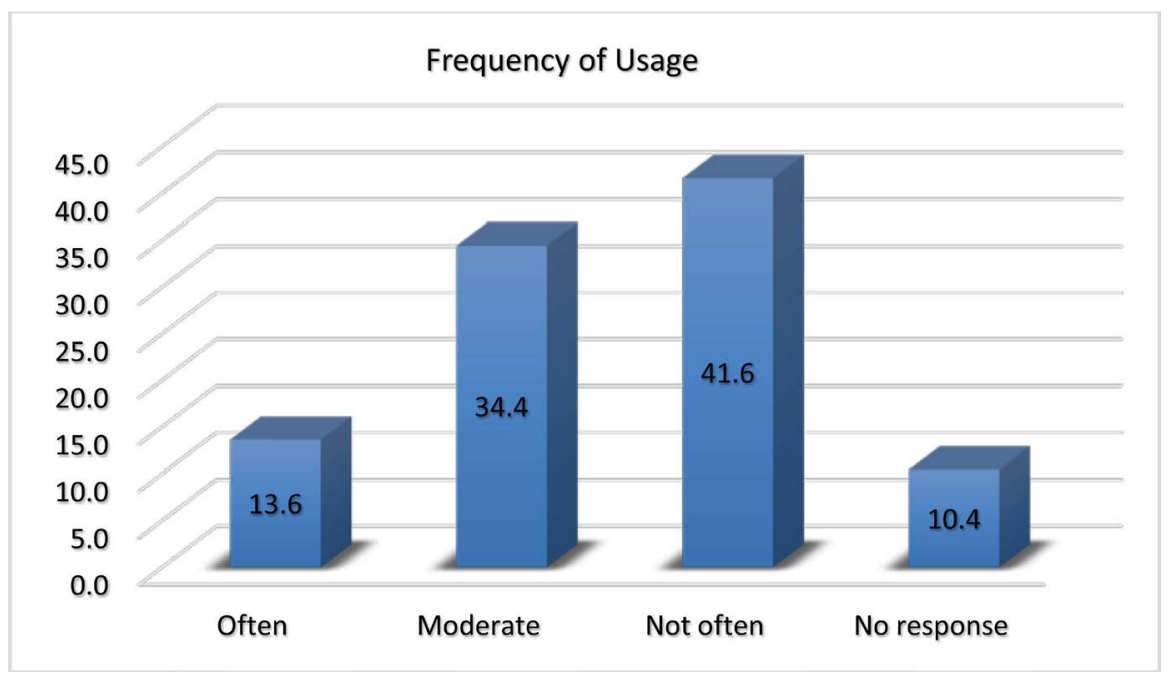

Figure 1. Percentage frequency of usage of the call centre line.

Table 1. Percentage distribution of services called for.

\begin{tabular}{ccccc}
\hline Service called for & Yes & No & No response & Total \\
\hline Balance inquiries & 8 & 80 & 12 & 100 \\
Account transactions & 68 & 20 & 12 & 100 \\
Internet banking service & 13.6 & 74.4 & 12 & 100 \\
Failed internet banking services & 28.8 & 59.2 & 12 & 100 \\
Failed Mobile banking services & 46.4 & 41.6 & 12 & 100 \\
General inquiries & 16 & 72 & 12 & 100 \\
\hline
\end{tabular}


Table 2. Customers not satisfied with the service received.

\begin{tabular}{|c|c|c|c|c|c|}
\hline & & Frequency & Percent & Valid Percent & Cumulative Percent \\
\hline \multirow{7}{*}{ Valid } & Strongly disagree & 11 & 8.8 & 8.8 & 8.8 \\
\hline & Disagree & 53 & 42.4 & 42.4 & 51.2 \\
\hline & Neither agree nor disagree & 13 & 10.4 & 10.4 & 61.6 \\
\hline & Agree & 32 & 25.6 & 25.6 & 87.2 \\
\hline & Strongly agree & 3 & 2.4 & 2.4 & 89.6 \\
\hline & No response & 13 & 10.4 & 10.4 & 100 \\
\hline & Total & 125 & 100 & 100 & \\
\hline
\end{tabular}

42.2\% of the sampled respondents and according to the results in the table below disagreed that they were not satisfied with the service they received from the call centre agents, $25.6 \%$ of the respondents agreed that they were not satisfied with the service they received, $10.4 \%$ of the respondents neither agreed nor disagreed that they were not satisfied with the service $8.8 \%$ strongly disagreed that they were not satisfied with the service and $2.4 \%$ of the respondents strongly agreed that they were not satisfied with the service. These results suggest that on average the respondents thought that the call centre agents were professional and knowledgeable, they also considered that the agents acted in their best interest and that they were satisfied with the services that they received from the call centre agents. On the other hand, some respondents about $25.6 \%$ indicated that they were not satisfied with the services that they received from the contact centre agents.

\section{Challenges Experienced and Root causes}

In this section the researcher presents the root causes of the challenges experienced by customers when interacting with the call centre agents. The challenges experienced by customers were coded quantitatively and analysed as below. Furthermore, to deeply assess the root causes of the challenges that customers experience when using the outsourced offshore call centre, the background information of the respondents were used to assess the relationship if any with some of the challenges associated with the call centre agents.

\subsection{Agent Challenges in Giving Geographical Information about Zambia}

The results in Table 3 show the respondents' opinion on the call centre agent's challenges in giving information about the geography of Zambia. These results imply that the call centre agents are not aware of the general geographical information about the Zambia where their bank operates.

\subsection{Challenges in Giving Information about the Geography of the Country}

Table 4 shows that of the 27 respondents who indicated that call centre 
Table 3. Challenges in giving information about the geography of the country.

\begin{tabular}{llcccc}
\hline & Frequency & Percent & Valid Percent & Cumulative Percent \\
\hline \multirow{2}{*}{ Yes } & 27 & 21.6 & 21.6 & 21.6 \\
& No & 8 & 6.4 & 6.4 & 28 \\
\multirow{2}{*}{ Valid } & I don't know & 76 & 60.8 & 60.8 & 88.8 \\
& No response & 14 & 11.2 & 11.2 & 100 \\
& Total & 125 & 100 & 100 & \\
\hline
\end{tabular}

Table 4. Chi-square tests.

\begin{tabular}{cccc}
\hline & Value & df & Asymp. Sig. (2-sided) \\
\hline Pearson Chi-Square & $14.339^{\mathrm{a}}$ & 9 & 0.111 \\
Likelihood Ratio & 17.388 & 9 & 0.043 \\
Linear-by-Linear Association & 2.109 & 1 & 0.146 \\
N of Valid Cases & 125 & & \\
\hline
\end{tabular}

${ }^{a} 8$ cells $(50.0 \%)$ have expected count less than 5 . The minimum expected count is 0.58 . Chi-Square Tests.

agents had challenges in giving information about the geography of the country, $37 \%$ were between in the 17 to 27 age group, $29.6 \%$ belonged to the 28 to 38 and 39 to 49 age groups respectively and only $3.7 \%$ belonged to the 50 and above age group. These results reveal that younger customers felt that call centre agents had challenges in giving information about the geography of the country than those in the late 20s, early 30 s as well as elders above 50 years.

The Chi-square test statistic was found to be 14.339 while the p-value was found to 0.111 . This indicates that the p-values is larger than 5 percent level of significance meaning that the researcher fails to reject the fact that there is no relationship between age of a customer and their perception about call centre agents having challenges giving information about the geography of Zambia. This simply entails that there is a relationship between the two variables.

When asked if the call centre agents have local language barriers, the sampled respondents gave the results in Table 5: According to these results, the majority of the respondents, about $41.6 \%$ stated that they did not know whether call centre agents had local language barriers. Almost on the same percentage, $40.8 \%$ of the respondents stated that call centre agents had local language barriers while only $6.4 \%$ of the respondents said that the call centre agents did not have local language barriers and $11.2 \%$ of the respondents did not respond to the question. These results suggest that the call centre agents have local language barriers at best. These results are evident that outsourced offshore call centres are not equipped to deal with wide range of challenges experienced by the local customers. These results have shown that the customers that cannot understand the language of the agents and vice versa are prone not to be helped at all because of the language barrier. 


\subsection{Local Language Barriers}

Table 6 shows that of the 51 respondents who indicated that they experienced local language barriers from call centre agents, the majority about $51 \%$ were males and $49 \%$ were females.

The Chi-square test statistic was found to be 1.231 while the p-value was found to 0.745 . This indicates that the p-values is larger than 5 percent level of significance meaning that the researcher fails to reject the fact that there is no relationship between being male or female and them experiencing local language barriers from call centre agents. This simply entails that there is no relationship between the two variables.

\subsection{Views on Local Call Centre}

Results in Table 7 show the sampled respondents' views on whether they thought having a local call centre would help mitigate the challenges currently experienced with the outsourced call centre. From the results obtained, the majority

Table 5. Local language barriers.

\begin{tabular}{llcccc}
\hline & Frequency & Percent & Valid Percent & Cumulative Percent \\
\hline Yes & 51 & 40.8 & 40.8 & 40.8 \\
No & 8 & 6.4 & 6.4 & 47.2 \\
Valid & I do not know & 52 & 41.6 & 41.6 & 88.8 \\
& No response & 14 & 11.2 & 11.2 & 100
\end{tabular}

Table 6. Chi-square tests.

\begin{tabular}{cccc}
\hline & Value & Df & Asymp. Sig. (2-sided) \\
\hline Pearson Chi-Square & $1.231^{\mathrm{a}}$ & 3 & 0.745 \\
Likelihood Ratio & 1.247 & 3 & 0.742 \\
Linear-by-Linear Association & 1.198 & 1 & 0.274 \\
N of Valid Cases & 125 & & \\
\hline
\end{tabular}

a 2 cells $(25.0 \%)$ have expected count less than $5 \%$. The minimum expected count is 3.97 .

Table 7. Views on having a local call centre.

\begin{tabular}{|c|c|c|c|c|}
\hline $\begin{array}{l}\text { Do you think having a local contact centre would } \\
\text { mitigate the challenges currently experienced } \\
\text { with the out sourced call centre? }\end{array}$ & Frequency & Percent & $\begin{array}{c}\text { Valid } \\
\text { Percent }\end{array}$ & $\begin{array}{c}\text { Cumulative } \\
\text { Percent }\end{array}$ \\
\hline Yes & 93 & 74.4 & 74.4 & 74.4 \\
\hline No & 15 & 12 & 12 & 86.4 \\
\hline No response & 17 & 13.6 & 13.6 & 100 \\
\hline Total & 125 & 100 & 100 & \\
\hline
\end{tabular}

Chi-Square Tests. 
(74\%) of the respondents indicated that having a local call centre could help mitigate the challenges being experienced in the current model of the call centre, $12 \%$ of the respondents did not think so. $14 \%$ of the respondents did not respond to this question. In general, these results show that indeed having a local call centre would significantly help mitigate the challenges that respondents are experiencing with the current offshore, out sourced call centre.

Views on Having a Local Call Centre.

\section{Results Discussion and Conclusion}

In order to ensure excellent service delivery by the call centre agents, the respondents suggested and the study concluded the following:

1) Having a local call centre would be helpful as customers that are not very conversant with English can easily use local languages and will also overcome the issue of culture barriers as agents and customer will be able to relate better.

2) Agents should acquire more knowledge on various products to be more effective and efficient. Therefore, consistent training is very much required.

3) Agents should be answering all calls on time as well as giving satisfying information.

4) The bank should engage in after service follow ups and get feedback from customers on how they can be served better. This can be done on a quarterly basis or bi annually.

5) Agents to have full on knowledge on locations of various ATMs and Branches across the country to help those customers that may need not know the nearest ATM or branch from their location.

6) The bank should engage mobile service provider $C$ to make the network toll free in order to accommodate its customers, engage mobile service providers A and $\mathrm{B}$ to improve the quality of connectivity.

Once the banks address the challenges using the pointers given by customers it would definitely help to deliver excellent service to the customers and also help increase market share and revenue.

\section{Conflicts of Interest}

The authors declare no conflicts of interest regarding the publication of this paper.

\section{References}

Abdullateef, A. O., Muktar, S. S. M., Yusoff, R. Z., \& Ahmad, I. S. B. (2014). Effects of Customer Relationship Management Strategy on Call Centre's Employee Intention to Quit: Evidence from Malaysia Call Centers. Procedia-Social and Behavioral Sciences, 130, 305-315. https://doi.org/10.1016/j.sbspro.2014.04.036

Afrika, A. (2012). The Way Forward. http://www.ebizradio.com

Amadeo, K. (2019).

https://www.thebalance.com/how-does-call-center-outsourcing-affect-the-u-s-econom $\mathrm{y}-3306191$ 
Amoako, G. (2012). Improving Customer Service in The Banking Industry-Case of Ghana Commercial Bank (GCB)—Ghana. International Business Research, 5, 134-148. https://doi.org/10.5539/ibr.v5n4p134

Angelova, B. \& Zeqiri, C. (2011). Measuring Customer Satisfaction with Service Quality Using American Customer Satisfaction Model (ACSI Model). International Journal of Academic Research in Business and Social Sciences, 1, 232-258.

Belyh, A. (2016). In-House or Outsourced Call Center. https://www.cleverism.com/in-house-vs-outsourced-call-centers-what-to-choose/

Clinton, A., \& Wellington, T. (2013). A Theoretical Framework of Users' Satisfaction/Dissatisfaction Theories and Models. 2nd International Conference on Arts, Behavioural Sciences and Economics Issues (ICABSEI'2013), 17-18 December 2013, Pattaya, Thailand, 48-53.

Dudovskiy, D. (2016). The Ultimate Guide to Writing A Dissertation In Business Studies. A Step by Step Assistance (1st ed.). Research methodology.

Global Contact Center Survey (2013).

https://www2.deloitte.com/us/en/pages/operations/articles/2013-global-contact-centersurvey.html

Govender, K. K. (2016). Outsourcing In-Bound Call Centers: Impact on Customers' Service Experience. Journal of Accounting \& Marketing, 5, Article ID: 1000187. https://doi.org/10.4172/2168-9601.1000187

Jouini, O., Pot, A., Koole, G., \& Dallery, Y. (2010). Online Scheduling Policies for Multiclass Call Centres with Impatient Customers. European Journal of Operational Research, 207, 258-268. https://doi.org/10.1016/j.ejor.2010.02.036

Kalaiselvi, D. K. (2016). Service Quality: Measurements and Management. IOSR Journal of Business Management, 23-25.

Khadka, K., \& Maharjan, S. (2017). Customer Satisfaction and Customer Loyalty.

Kim, B., Park, K. S., Jung, S. \& Park, S. H. (2017). Offshoring and Outsourcing in a Global Supply Chain: Impact of the Arm's Length Regulation on Transfer Pricing. European Journal of Operational Research, 266, 88-98. https://doi.org/10.1016/j.ejor.2017.09.004

Kim, J. W., \& Ha, S. H. (2010). Consecutive Staffing Solution Using Simulation in the Contact Center. Industrial Management \& Data Systems, 110, 718-730. https://doi.org/10.1108/02635571011044740

Koeck, B., \& Marshall, D. V. (2015). Word of Mouth Theory Revisited: The Influence of New Actors on Seeding Campaigns. In K. Diehl, \& C. Yoon (Eds.), NA-Advances in Consumer Research (Vol. 43, pp. 374-378). Duluth, MN: Association for Consumer Research.

Kranias, A., \& Bourlessa, M. (2010). Investigating the Relationship between Service Quality and Loyalty in Greek Banking Sector. Procedia Economics and Finance, 5, 453-458. https://doi.org/10.1016/S2212-5671(13)00053-1

Kurniali, S., \& Titan (2015). Customer Service Information for a Call Centre. Procedia Computer Science, 59, 298-304. https://doi.org/10.1016/j.procs.2015.07.569

Kurtovic, E., \& Hasimbegovic, A. (2015). Measuring Customer Service Level in Banking Sector Applying Mystery Calls Method and Its Relation to HR Department. The Business \& Management Review, 6, 1-11.

Lywood, J., Stone, M., Ekinci, Y. (2009). Customer Experience and Profitability: An Application of the Empathy Rating Index (ERIC) in UK Call Centres. Journal of Database Marketing and Customer Strategy Management, 16, 207-214.

https://doi.org/10.1057/dbm.2009.24 
Rouse, M. (2017). Call Centre.

Tao, F. F. (2014). Customer Relationship Management Based on Increasing Customer Satisfaction. International Journal of Business and Social Science, 5, 256-263.

Webber, E. A., \& Brown, E. G. (2008). B2B Customer Experience Priorities in an Economic Downturn: Key Customer Usability Initiatives in a Soft Economy. Report.

Xia, Y., Chen, B., Jayaramand, V., \& Munsone, C. L. (2015). Competition and Market Segmentation of the Call Centre Service Supply Chain. European Journal of Operational Research, 247, 504-514. https://doi.org/10.1016/j.ejor.2015.06.027

Zhu, X. W. (2016). Managing the Risks or Outsourcing: Time, Quality and Correlated Costs. Transportation Research Part E: Logistics and Transportation Review, 90, 121-133. https://doi.org/10.1016/j.tre.2015.06.005 